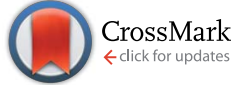

Cite this: RSC Adv., 2015, 5, 80203

\title{
Novel FeOx-polyethylene transparent films: synthesis and mechanism of surface regeneration
}

\begin{abstract}
S. Rtimi, ${ }^{\star a}$ C. Pulgarin, ${ }^{* a}$ R. Sanjines ${ }^{b}$ and J. Kiwi ${ }^{a}$
The first evidence for the synthesis of a uniform, adhesive polyethylene-FeOx (PE-FeOx) surface leading efficiently to bacterial inactivation is addressed in this study. PE was loaded with $0.04-0.08 \% \mathrm{Fe}$ wt/wt $\mathrm{PE}$ after RF-plasma pretreatment was required to increase the active sites/polarity and roughness to adhere FeOx on PE. The repetitive bacterial inactivation proceeded in a stable way for several cycles. The oxidative radicals leading to bacterial inactivation under aerobic/anaerobic conditions were investigated by the use of appropriate scavengers. By X-ray photoelectron spectroscopy (XPS) and diffuse reflection spectroscopy (DRS) the changes on the PE-FeOx oxidation states and spectroscopic features during bacterial inactivation were monitored. The regeneration of the initial Fe-oxidation state and consequently of the initial Fe-oxidation state in the PE-FeOx was possible and followed by DRS. Inductive plasma coupled mass spectrometry (ICP-MS) indicated that only sub-ppb levels of Fe were released from the $\mathrm{PE}-\mathrm{FeO}$ surface within the reaction time.
\end{abstract}

Received 22nd July 2015

Accepted 15th September 2015

DOI: $10.1039 / \mathrm{c} 5 \mathrm{ra14503a}$

www.rsc.org/advances

\section{Introduction}

Iron oxide nanoparticles (NP's) are of considerable interest due to their wide applications in fields such as magnetic storage, medicine, chemical industries, catalytic materials and water purification. ${ }^{1}$ Nanoparticle syntheses of $\mathrm{Fe}_{2} \mathrm{O}_{3}$, $\mathrm{FeO}$ and $\mathrm{Fe}_{3} \mathrm{O}_{4}$ have been carried out by precipitation, sol-gel, hydrothermal, dry vapour deposition, surfactant mediation, micro-emulsion, electro-deposition and sonochemical methods. ${ }^{2}$ To avoid the work, time and reagents needed after catalysis induced by FeOx based suspensions, polymer-based FeOx films are an active area of research in biomaterials, protective coatings and medical bactericide devices. ${ }^{3-5}$ But the deposition/annealing of colloids on many thermally resistant surfaces required temperatures of a few hundred degrees and this is only possible on substrates withstanding high temperatures. When depositing colloids of metals/oxides on polymers the attachment of colloids is weak, not entirely reproducible and do not withstand friction being also easily wiped off from the polymer surface..$^{6-9}$

In this study, we have selected polyethylene (PE) as substrate to sputter FeOx by direct current magnetron sputtering (DCMS) since $\mathrm{PE}$ it is a flexible low cost polymer resistant to corrosion and withstands $120^{\circ} \mathrm{C}$ within the short times. The low surface energy of $\mathrm{PE}$ is the major reason for the poor particle adhesion leading to $\mathrm{Fe}-$ polymer composites. We focus on the binding of FeOx on PE as an innovative catalyst for bacterial disinfection. RF-pretreatment of PE

${ }^{a}$ Ecole Polytechnique Fédérale de Lausanne, EPFL-SB-ISIC-GPAO, Station 6, CH-1015, Lausanne, Switzerland.E-mail: sami.rtimi@epfl.ch; cesar.pulgarin@epfl.ch;Tel: +41 216935150

${ }^{b}$ Ecole Polytechnique Fédérale de Lausanne, EPFL-SB-IPMC-LPCM, Station 3, CH1015, Lausanne, Switzerland has been carried out to fix a suitable amount of FeOx on the pretreated PE-hydrophilic sites. ${ }^{10}$ The $\mathrm{FeO}_{\mathrm{X}}$ was then deposited on $\mathrm{PE}$ by sputtering in a magnetron chamber ${ }^{11}$ and the amount of $\mathrm{FeOx}$ on the PE surface inactivated bacteria with acceptable kinetics.

During the last decades, iron oxide colloids have been reported as a photocatalyst in aqueous solutions to inactivate pollutants ${ }^{12}$ and also as a photocatalyst able to inactivate $E$. coli via photo-Fenton like processes in aqueous suspensions. ${ }^{13-15}$ When using Fe-oxides in suspension, separation and filtration of the catalyst at the end of the process is necessary for the catalyst reuse. For this reason our laboratory has reported degradation of pollutants on Fe-supported on PE-maleic anhydride films ${ }^{16,17}$ and also on Fe-sulfonic Nafion exchange membranes. ${ }^{18}$

Resistance of some bacteria to antibiotics is serious health problem leading to increased hospital-acquired infections (HAI). ${ }^{19,20}$ Antibiotic resistant bacteria induce healthcareacquired infections (HCAI) with its associated high care costs. ${ }^{21}$ For this reason, there is a need at the present time to develop innovative composite surfaces and materials with faster antibacterial bacterial kinetics, like polymer films, rugs, curtains, medical devices and catheters.

The present study focuses on the preparation of innovative PE-FeOx uniform, adhesive, efficient and stable surfaces that can regenerated easily. We do not address the detailed mechanism of these Fe-oxide bacterial interaction surfaces but we address the photocatalysis presenting a systematic analysis of the surface properties. Therefore we focus on: (a) the optimization of the PE-surface pretreatment by RF-plasma to graft FeOx by reactive magnetron sputtering, (b) the evaluation of the E. coli inactivation kinetics and mechanism on PE-FeOx surfaces during the recycling of the catalyst and (c) the analysis/ 
description of the PE-FeOx microstructure by surface science techniques to characterize the PE-FeOx films.

\section{Experimental}

\section{RF-plasma pretreatment preceding the PE-FeOx sputtering on PE films}

The polyethylene fabrics were pretreated in the cavity of the RFplasma unit (Harrick Corp. $13.56 \mathrm{MHz}, 100 \mathrm{~W}$ ) at a pressure of 1 Torr. The topmost PE-layers of $2 \mathrm{~nm}(\sim 10$ atomic layers) were RF-plasma pretreated for $5 \mathrm{~min}, 10 \mathrm{~min}$, and $15 \mathrm{~min}$. Oxygen RF-produced plasma reacts with the $\mathrm{PE}$ surface to induce surface groups like $\mathrm{C}-\mathrm{O}, \mathrm{C}=\mathrm{O}, \mathrm{O}-\mathrm{C}=\mathrm{O}, \mathrm{C}-\mathrm{O}-\mathrm{O}-$. This pretreatment modifies the PE surface by: (a) etching of the PE surface due to the residual O-radicals still present in the gas of the RF-plasma chamber at 1 Torr, (b) introducing hydrophilic groups on the PE-surface and (c) breaking the intermolecular $\mathrm{PE}$ - and the $\mathrm{H}-\mathrm{H}$ bonds leading to a partial segmentation of PE. FeOx then binds the PE-negative functionalities by electrostatic attraction and chelation/complexation. ${ }^{10,11}$

The FeOx was sputtered from a $5 \mathrm{~cm}$ diameter target (Kurt Lesker, East Sussex, UK) by direct current magnetron sputtering (DC) on PE. Since Fe is paramagnetic, the target was modified by creating an artificial eroded zone by electro-erosion in order to let the magnetic field pass through the target forcing the electrons to follow a hopping trajectory along the target. The residual pressure $P_{\mathrm{r}}$ in the sputtering chamber was adjusted to $P_{\mathrm{r}} 10^{-4} \mathrm{~Pa}$. The substrate to target distance was set at $10 \mathrm{~cm}$. The FeOx films were deposited by reactive DC-magnetron sputtering (DC) in an $\mathrm{O}_{2}$ gas flow. The thickness of the FeOx sputtered layers was determined by means of a profilometer (Alphastep500, Tencor).

The polyethylene (PE) consists of highly branched low crystalline semi-transparent film with the formula $\mathrm{H}\left(\mathrm{CH}_{2}-\mathrm{CH}_{2}\right)_{n} \mathrm{H}$. The (LDPE) $0.1 \mathrm{~mm}$ thick was obtained from Longfellow, UK (ET3112019), had a density of $0.92 \mathrm{~g} \mathrm{~cm}^{-3}$, and a flowing point of $185{ }^{\circ} \mathrm{C}$. The PE was prepared by Blown Film Extrusion manufacturing.

\section{X-ray fluorescence (XRF), diffuse reflectance spectroscopy (DRS) and atomic force microscopy (AFM)}

The Fe-content sputtered on PE film was evaluated by X-ray fluorescence (XRF) in a PANalytical PW2400 spectrometer. Diffuse reflectance spectroscopy was carried out in a Perkin Elmer Lambda 900 UV-VIS-NIR spectrometer provided for with a PELA-1000 accessory within the wavelength range of 200-800 $\mathrm{nm}$ and a resolution of one $\mathrm{nm}$. The AFM images were acquired in contact mode using a PSIA Xe-100 instrument. The AFM scanner and position sensors were calibrated using standard samples from Mikromash. The experimental error in the roughness values was below $10 \%$. The mean surface roughness $\left(R_{\mathrm{a}}\right)$ was calculated from the scanned area.

\section{E. coli inactivation and bacterial stereomicroscopy on PE- FeOx films and irradiation procedures}

The samples of Escherichia coli (E. coli K12 ATCC23716) on $2 \mathrm{~cm}$ by $2 \mathrm{~cm}$ PE-FeOx were placed into a glass Petri dish and irradiated in the cavity reactor. The $100 \mu \mathrm{L}$ culture aliquots with an initial concentration of $\sim 10^{6}$ colony forming units (CFU $\mathrm{mL}^{-1}$ ) in $\mathrm{NaCl} / \mathrm{KCl}(\mathrm{pH} 7$ ) were placed on sputtered PE. After preselected irradiation times, the fabric was transferred into a sterile $2 \mathrm{~mL}$ Eppendorf tube containing $1 \mathrm{~mL}$ autoclaved $\mathrm{NaCl} /$ $\mathrm{KCl}$ saline solution. This solution was subsequently mixed thoroughly using a Vortex for $3 \mathrm{~min}$. Serial dilutions were made in $\mathrm{NaCl} / \mathrm{KCl}$ solution. Samples of $100 \mu \mathrm{L}$ were pipetted onto a nutrient agar plate and then spread over the surface of the plate using standard plate method. Agar plates were incubated lid down, at $37{ }^{\circ} \mathrm{C}$ for $24 \mathrm{~h}$ before counting. Three independent assays were done for each sputtered sample. The PE-FeOx films were kept in a sterile oven at $60^{\circ} \mathrm{C}$ to avoid contamination prior to the bacterial test. The $100 \mu \mathrm{L}$ bacteria samples were well distributed on the uniform PE-FeOx samples. Irradiation of the $\mathrm{PE}-\mathrm{FeOx}$ samples was carried out on glass Petri dishes provided with a lid to prevent evaporation in the Suntest irradiation cavity. The agar was purchased from Merck GmbH, Microbiology division KGaA under the catalogue No. 1.05463.0500. The CFU statistical analysis was performed calculating the standard deviation values. After a bacterial inactivation cycle, the film was regenerated by immersion in $10 \mathrm{~mL} \mathrm{NaOH} \mathrm{(1} \mathrm{M)} \mathrm{for} 15 \mathrm{~min}$.

The fluorescence stereomicroscopy was carried out on samples inoculated with $10^{8} \mathrm{CFU}$ of $E$. coli and incubated for 2 hours in a humidification chamber. This method uses a fluorochrome-based staining procedure from Filmtracer ${ }^{\mathrm{TM}}$ LIVE/DEAD ${ }^{\circledR}$ Biofilm Viability Kit (Molecular Probes, Invitrogen). The kit contains a combination of the SYTO ${ }^{\circledR} 9$ green fluorescent nucleic acid stain and propidium iodide fluorochromes for the staining of live and dead cells, respectively. The sample fluorescence was monitored in a fluorescence stereomicroscope (Leica MZ16 FA, Leica Microsystems GmbH Wetzlar, Germany) and the images were processed using the LAS v.1.7.0 build 1240 software from Leica Microsystems CMS $\mathrm{GmbH}$. Adhesion of bacteria to the sputtered PES was allowed for 2 min before washing the sample with sterile Milli-Q water to remove non-adherent bacteria.

The PE-FeOx films were irradiated with the Xe- $400 \mathrm{~W}$ light in the Suntest solar simulator CPS (Atlas GmbH, Hanau, Germany) with a light dose of $52 \mathrm{~mW} \mathrm{~cm}{ }^{-2}\left(\sim 0.8 \times 10^{16}\right.$ photons per s) and a cut-off filter was added in the Suntest cavity to block the light $<310 \mathrm{~nm}$.

\section{Bacterial adhesion on PE-FeOx and $\mathrm{pH}$ evolution during disinfection}

The E. coli adhered on the PE-FeOx surface was evaluated immersing the PE-FeOx samples into $5 \mathrm{~mL}$ of $E$. coli cell suspension and subsequently shaking gently at $37^{\circ} \mathrm{C}$ for $4 \mathrm{~h}$ in dark..$^{25}$ Non-adhered bacteria were removed by washing the PE with phosphate buffer solution ( $\mathrm{pH}$ 7.2). The number of viable cells was determined after removal of the adhered $E$. coli cells by ultrasonication for $15 \mathrm{~min}$.

The local $\mathrm{pH}$-changes during the bacterial inactivation was followed by a Jenco $6230 \mathrm{~N}(\mathrm{pH} / \mathrm{mV} / \mathrm{Temp}$ meter) provided for with a hand held microprocessor in splash proof case with 3 points calibration. The device can be monitored via RS-232-C 
IBM compatible communication interface and BNC, $\mathrm{pH} / \mathrm{ORP}$ connector with 8-pin DIN ATC connector.

\section{XPS and Fe-leaching determination by inductively coupled plasma mass-spectrometry (ICP-MS)}

The X-ray photoelectron spectroscopy (XPS) of the PE-FeOx films was determined using an AXIS NOVA photoelectron spectrometer (Kratos Analytical, Manchester, UK) provided for with monochromatic $\mathrm{AlK}_{\alpha}(h \nu=1486.6 \mathrm{eV})$ anode. The carbon C $1 \mathrm{~s}$ line with position at $284.6 \mathrm{eV}$ was used as a reference to correct the charging effect. The surface atomic concentration was determined from peak areas using the known sensitivity factors for each element. ${ }^{22,23}$ The spectrum background was subtracted according to Shirley. ${ }^{24}$ The XPS spectral peaks of FeOx were deconvoluted with a CasaXPS-Vision 2, Kratos Analytical UK.

The Finnigan ${ }^{\mathrm{TM}}$ ICPS used was equipped with a double focusing reverse geometry mass spectrometer with an extremely low background signal and a high ion-transmission coefficient. The FeOx of the samples was digested with nitric acid $69 \%$ (1: 1 $\mathrm{HNO}_{3}+\mathrm{H}_{2} \mathrm{O}$ ) to remove the organics in the solution and to guarantee that there were no remaining ions adhered to the flacon wall. The samples droplets are introduced to the ICP-MS trough a peristaltic pump to the nebulizer chamber at $\sim 7700^{\circ} \mathrm{C}$ allowing the sample components evaporation and ionization. The Fe found in the nebulizer droplets was subsequently quantified by mass spectrometry (MS).

\section{Results and discussion}

\section{PE-film pretreatment by RF-plasma and its effect on film roughness}

Fig. 1 presents the increase in the absorption of the PE film as a function of RF-plasma pretreatment time.

In the presence of residual oxygen, RF-plasma leads to the build-up of $\mathrm{C}-\mathrm{O}$ groups on $\mathrm{PE}$ surface such as: $\mathrm{C}=\mathrm{O}\left(\mathrm{n} \rightarrow \Pi^{*}\right.$ $\left.280 \mathrm{~nm} \varepsilon=20 \mathrm{M}^{-1} \mathrm{~cm}^{-1}\right) ; \mathrm{C}=\mathrm{C}-\mathrm{C}=\mathrm{O}\left(\mathrm{n} \rightarrow \Pi^{*} 220 \mathrm{~nm} \varepsilon=2 \times\right.$ $\left.10^{5} \mathrm{M}^{-1} \mathrm{~cm}^{-1}\right)$ and $\mathrm{C}=\mathrm{C}-\mathrm{C}=\mathrm{O}\left(\mathrm{n} \rightarrow \Pi^{*} 290 \mathrm{~nm} \varepsilon=30 \mathrm{M}^{-1}\right.$

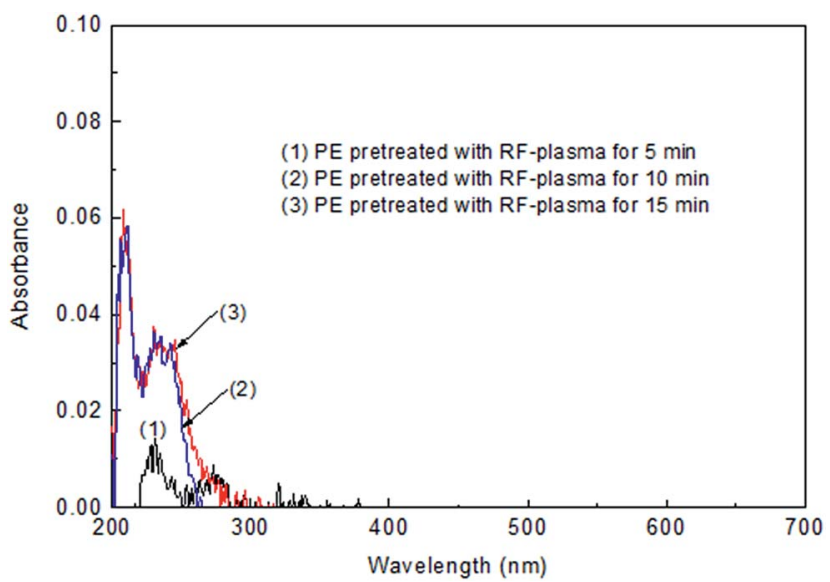

Fig. 1 Diffuse reflectance spectroscopy (DRS) spectra of RF-plasma pre-treated polyethylene (PE) surfaces at a pressure of 1 Torr. $\left.\mathrm{cm}^{-1}\right) .{ }^{26}$ RF-plasma at 1 Torr enhances the capture length of the electrons generated by the applied electric field leading to excited $\mathrm{O}^{*}$ and atomic $\mathrm{O}$, singlet ${ }^{1} \mathrm{O}_{2}$, anion-radicals $\mathrm{O}^{-}$and cation-radicals $\mathrm{O}^{+} .^{27}$ These species react with the PE surface introducing oxidative $\mathrm{C}-\mathrm{O}$ type functionalities, breaking $\mathrm{H}-\mathrm{H}$ and $\mathrm{C}-\mathrm{C}$ bonds segmenting the $\mathrm{PE}$-film. ${ }^{28}$ Concomitantly oxidative functionalities like: $-\mathrm{C}-\mathrm{O}^{-},-\mathrm{COO}^{-},-\mathrm{COH}-, \mathrm{O}-\mathrm{C}=$ $\mathrm{O}^{-},-\mathrm{COOH}$, percarboxylates, epoxides, phenolic and lactam and these negative polar groups by electrostatic attraction bind positive $\mathrm{Fe}^{3+}$-cation (FeOx) leading to surface coordination/ chelation. ${ }^{29}$ The residual $\mathrm{H}_{2} \mathrm{O}$-vapor still present in the chamber being decomposes during the sputtering being an additional source of O-atoms and O-ions.

The changes in the concentration of the oxidative functional groups $\mathrm{C}-\mathrm{OH}, \mathrm{C}=\mathrm{O}$ and $\mathrm{O}=\mathrm{C}-\mathrm{OH}$ and the ratio to the $\mathrm{C}-\mathrm{C}$, $\mathrm{C}=\mathrm{C}$ and $-\mathrm{CH}_{2}$ reductive species obtained by XPS are shown in Fig. 2a. Fig. 2b shows the $\mathrm{C}$ 1s deconvolution before and after RF-plasma pretreatment supporting the results found in Fig. 2a.
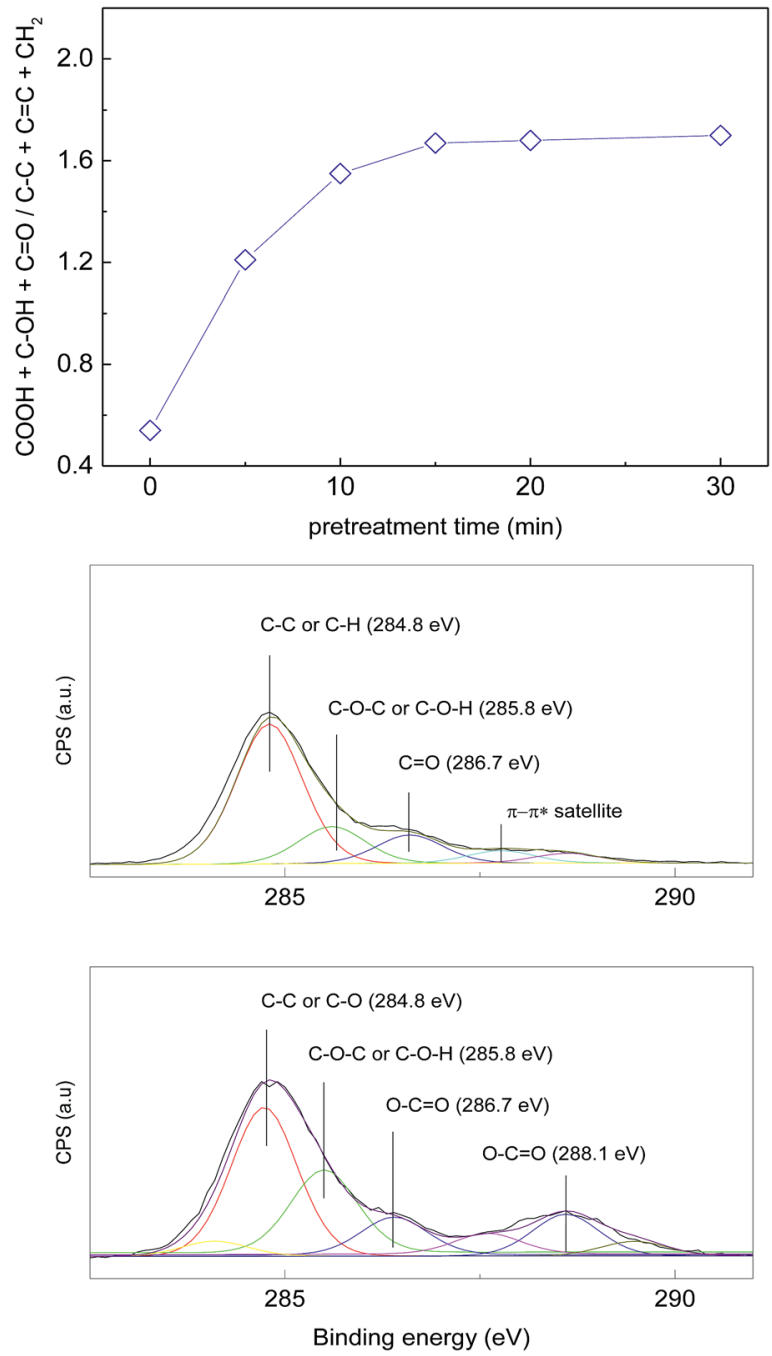

Fig. 2 (a) Ratio of the oxidized to reduced functionalities $(\mathrm{COOH}+\mathrm{C}-$ $\mathrm{OH}+\mathrm{C}=\mathrm{O} / \mathrm{C}-\mathrm{C}+\mathrm{C}=\mathrm{C}+\mathrm{CH}_{2}$ ) introduced by RF-plasma pretreatment at 1 Torr on PE as a function of time. (b) High resolution XPS $\mathrm{C}$ 1s deconvolution before and after RF-plasma pretreatment. 
The deconvoluted peaks centred at BE of 285.9, 286.6 and $288.1 \mathrm{eV}$ were ascribed respectively to the $\mathrm{C}-\mathrm{OH}, \mathrm{C}=\mathrm{O}$ and $\mathrm{O}=$ $\mathrm{C}-\mathrm{OH}$ according to their binding energy (BE) values. ${ }^{22-24}$ The binding energy (BE) at $285.0 \mathrm{eV}$ was assigned to the $\mathrm{C}-\mathrm{C}, \mathrm{C}=\mathrm{C}$ and $\mathrm{CH}$ (reduced functionalities) to estimate the values in the $y$ axis in Fig. 2a. The ratio of oxidized to reduced functionalities $(\mathrm{COOH}+\mathrm{COH} / \mathrm{CH}+\mathrm{C}-\mathrm{C})$ remained constant beyond $20 \mathrm{~min} \mathrm{RF}-$ pretreatment, at the time the highest polarity was reached on the PE-film. .0-32 $^{\text {30 }}$

Fig. 3 shows the roughness of the PE-films as a function of the RF-plasma pretreatment times. The root mean square (rms) of the samples pretreated at times (a) zero, (b) $5 \mathrm{~min}$ and (c) 10 min led to $R_{\mathrm{g}}$ values of $3 \mathrm{~nm}, 7 \mathrm{~nm}$ and $13 \mathrm{~nm}$ respectively. The increased non-uniformity in the topmost PE fibers introduced at an RF-plasma pretreatment time of $10 \mathrm{~min}$ is consistent with the time necessary to introduce the highest polarity on the PEFeOx as shown in Fig. 2.

Bacterial adhesion, bacterial inactivation followed by plate counting, and stereomicroscopy of live/dead bacteria

The bacterial adhesion as a function of the contact time increased on pretreated $\mathrm{PE}-\mathrm{FeOx}$ compared to non-pretreated PE-FeOx surfaces as seen in Fig. 4.

This trend was also similar to the trend reported in Fig. 3 for $R_{\mathrm{g}}$ values as a function of the RF pretreatment time suggesting that the surface roughness had a significant effect on bacterial adhesion. The diffusion of the generated ROS by the PE-FeOx film under light on the bacterial load ( $100 \mu \mathrm{L}$ samples) allows to kill also the non-adhered or the weakly adhered bacteria. The weakly adhered bacteria could be removed by sonication.

Fig. 5 a presents the $E$. coli inactivation under solar simulated light and in the dark on 10 min RF pretreated PE-FeOx with different Fe-loadings (Table 1).

PE-FeOx sputtered for $60 \mathrm{~s}$ led to the faster bacterial inactivation time (Fig. 5a, trace 2 ).

Table 2 shows that the half time for bacterial inactivation (E50\%) depends on the time of sputtering of Fe on PE leading to PE-FeOx films.

The thickness determined by profilometry of the FeOx layer of $42 \mathrm{~nm}$. This layer thickness seems to induce the most
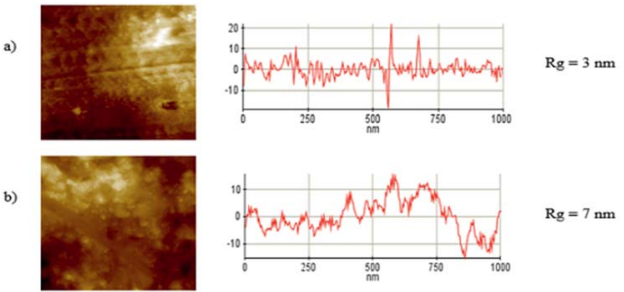

c)
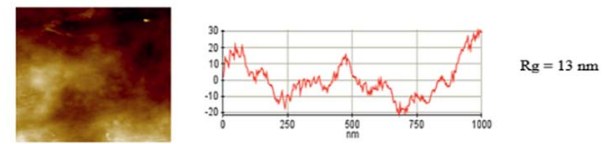

Fig. 3 Roughness and topography of pre-treated PE films by RF plasma: (a) time zero, (b) $5 \mathrm{~min}$ and (c) $10 \mathrm{~min}$. For other details see Ms text.

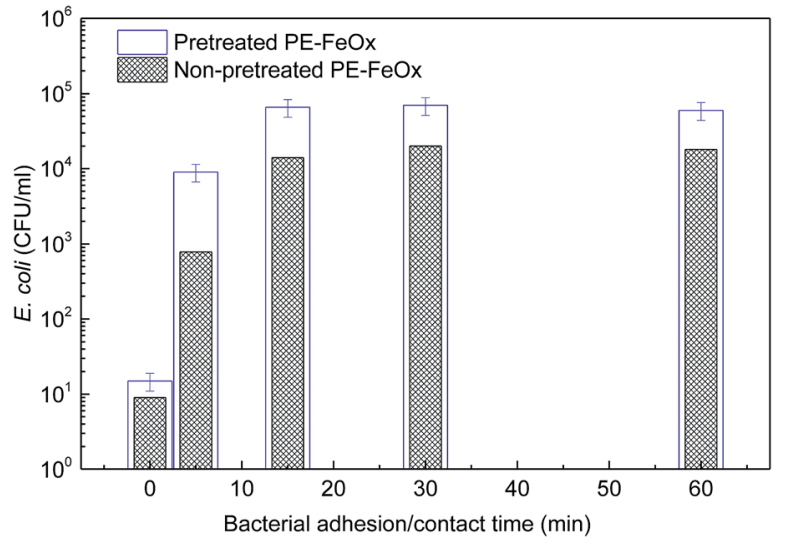

Fig. 4 E. coli adhesion on PE-FeOx sputtered for $60 \mathrm{~s}$ : ( $\square$ ) RF-plasma pre-treated surface for $15 \mathrm{~min}$ and $(\square) \mathrm{PE}-\mathrm{FeOx}$ sputtered for $60 \mathrm{~s}$ non-pre-treated surface.
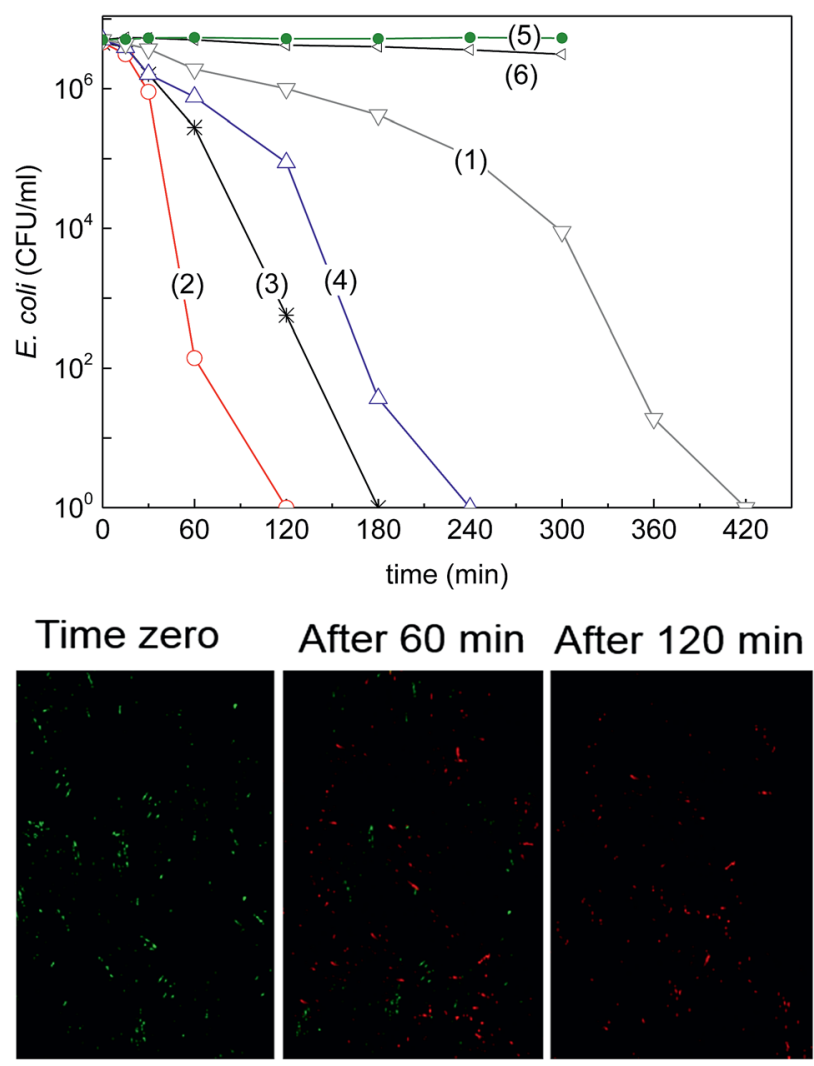

Fig. 5 (a) E. coli reduction on $\mathrm{PE}-\mathrm{FeOx}$ pre-treated surfaces and sputtered for (1) $30 \mathrm{~s}$, (2) $60 \mathrm{~s}$, (3) $120 \mathrm{~s}$, (4) $150 \mathrm{~s}$ and illuminated with solar simulated light $\left(52 \mathrm{~mW} \mathrm{~cm}^{-2}\right)$. (5) PE-FeOx sputtered for $60 \mathrm{~s}$ in the dark and (6) unsputtered PE under solar simulated light irradiation. (b) Stereomicroscopy of live bacteria (green dots) followed by dead bacterial (red dots) cells on PE-FeOx at time zero, after $60 \mathrm{~min}$ and after 120 min of irradiation by Suntest simulated solar radiation.

suitable size/surface loading of the FeOx clusters on the PE. If one atomic layer is $\sim 0.2 \mathrm{~nm}$ thick and including $10^{15}$ atoms per $\mathrm{cm}^{2}$, the Fe deposition rate can be estimated as $3.5 \times 10^{15}$ atoms per $\mathrm{cm}^{2} \mathrm{~s} .{ }^{11}$ The number of Fe-layers sputtered within a 
Table $1 \quad \mathrm{Fe}_{2} \mathrm{O}_{3}$ loadings on PE samples detected $\mathrm{X}$-ray fluorescence spectroscopy (XPS) at time zero on PE

\begin{tabular}{lll}
\hline & Conc.\% $\mathrm{Fe}_{2} \mathrm{O}_{3}$ & Error\% \\
\hline FeOx-PE sputtered for $30 \mathrm{~s}$ & 0.0401 & 0.006 \\
FeOx-PE sputtered for $60 \mathrm{~s}$ & 0.0607 & 0.007 \\
FeOx-PE sputtered for $120 \mathrm{~s}$ & 0.0842 & 0.007
\end{tabular}

Table 2 Half-time for the bacterial reduction (E50\%) on PE-FeOx sputtered for different times under solar simulated low intensity irradiation $\left(52 \mathrm{~mW} \mathrm{~cm}^{-2}\right)$

FeOx-PE sputtered for $30 \mathrm{~s}$

thickness of $42 \mathrm{~nm}$ is $\sim 210$ layers. ${ }^{\mathbf{1 0}, 22}$ Sputtering for $30 \mathrm{~s}$ (trace 4) did not deposit enough FeOx on the PE (Table 1). The bacterial inactivation time shown in Fig. 5a, traces 3 and 4 reveal longer bacterial inactivation times for sputtering times of 120 and $150 \mathrm{~s}$, due to two effects: (a) the increase in layer thickness leading to bulk inward diffusion of the charge carriers $^{\mathbf{2 , 1 0}}$ and (b) the size of the FeOx-clusters increased with the sputtering time. This leads to FeOx agglomerates, but the catalytic activity per exposed atom would consequently decreases due to agglomeration..$^{2,6,9}$ Fig. 5a, trace 5 also shows that the bacterial inactivation does not take place in the dark on $\mathrm{PE}-\mathrm{FeOx}$ films nor does it proceed on PE alone under simulated solar irradiation.

Fig. 5b shows the live and dead $E$. coli bacteria by using the dye fluorochrome that enters the cell and stains the DNA when the cell wall membranes are damaged by PE-FeOx showing an abnormal high permeability. ${ }^{2,3}$

The time sequence for $E$. coli cells wall destabilization/ damage leading ultimately to cell dead is shown in Fig. 5b the increasing population of red dots. The red dots are indicative of cell membrane damage. On the other hand, bacterial cells incubated on PE alone kept alive up to 120 min light exposure remaining green.

\section{Recycling stability of PE-FeOx during bacterial inactivation and catalyst regeneration}

The PE-FeOx mediated bacterial repetitive inactivation is shown occurring within the same times in Fig. 6. This points out to the stable catalytic intervention of PE-FeOx as an antibacterial surface.

Fig. 7a shows the diffuse reflectance spectroscopy (DRS) of PE-FeOx samples up to the $5^{\text {th }}$ disinfection cycle in KubelkaMunk units. The spectrum of $\mathrm{Fe}_{2} \mathrm{O}_{3}$ between 250 and $500 \mathrm{~nm}$ has been reported and the amplitude of the $\mathrm{Fe}_{2} \mathrm{O}_{3}$ spectral peaks observed at 350, 300 and $265 \mathrm{~nm}$ are a function of the film

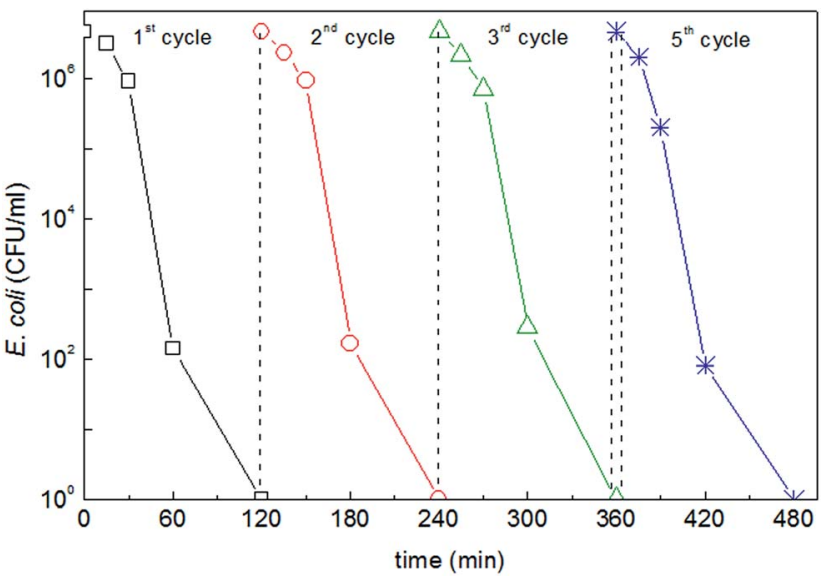

Fig. 6 Recycling of PE-FeOx sputtered samples for $60 \mathrm{~s}$ under low intensity solar simulated light $\left(52 \mathrm{~mW} \mathrm{~cm}^{-2}\right)$.
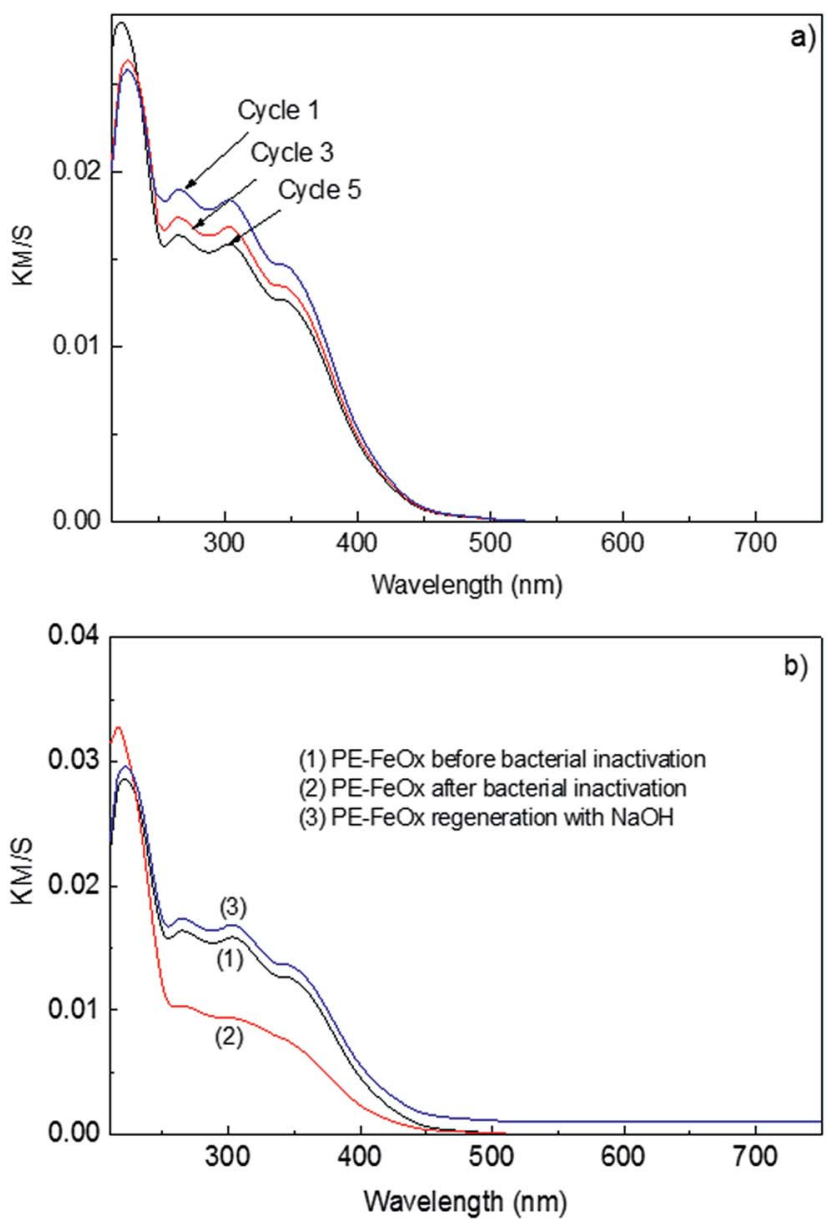

Fig. 7 (a) DRS spectra of PE-FeOx sputtered for $60 \mathrm{~s}$ after the 1st, 3rd and the 5th bacterial reduction cycles. Low intensity solar simulated light was used during the bacterial reduction $\left(52 \mathrm{~mW} \mathrm{~cm}^{-2}\right)$. (b) DRS spectra of PE-FeOx sputtered for $60 \mathrm{~s}$ before and after bacterial reduction. Trace (3) shows the DRS spectra of $\mathrm{PE}-\mathrm{FeO}$ x regenerated with $\mathrm{NaOH}$. Low intensity solar simulated light was used during the bacterial reduction $\left(52 \mathrm{~mW} \mathrm{~cm}^{-2}\right)$. 
thickness and $\mathrm{Fe}_{2} \mathrm{O}_{3}$ grain size. ${ }^{35,36}$ The peak around $220 \mathrm{~nm}$ in Fig. 7a is due to the PE optical absorption (Fig. 1). The stability of the PE-FeOx DRS spectra up to the $5^{\text {th }}$ recycling shown in Fig. 7a is consistent with sample cycling shown in Fig. 6. Fig. 7b, trace 1 reports the spectrum of $\mathrm{PE}-\mathrm{FeOx}$ before bacterial inactivation. Fig. 7b, trace 2, reports the spectrum of PE-FeOx after bacterial inactivation. The regeneration of the initial state of $\mathrm{Fe}_{2} \mathrm{O}_{3}$ (on the PE-FeOx surface) was possible by the use of a $1 \mathrm{M}$ $\mathrm{NaOH}$ solution ${ }^{35}$ as it can be seen in Fig. 7b trace (3). $\mathrm{Fe}_{2} \mathrm{O}_{3}$ is an n-type semiconductor with a band-gap of $\sim 2.3 \mathrm{eV}$ able to activate charge separation on at a potential $\sim 0.1 \mathrm{eV}$ and holes at $+2.2 \mathrm{eV}^{35,36}$

The visual appearance of PE unsputtered samples and for PE-FeOx sputtered samples for $30 \mathrm{~s}, 60 \mathrm{~s}$ and $120 \mathrm{~s}$ are shown in Fig. 8. The blue line in Fig. 8 was added for clarity of presentation due to the transparent nature the FeOx-PE film. The orange-brown colour in the sample shown in Fig. 8c is characteristic of $\mathrm{Fe}_{2} \mathrm{O}_{3}$ in samples sputtered for $60 \mathrm{~s}$ figures in Fig. 8e shows the decrease in colour after 2 bacterial inactivation cycles and further discoloration is shown after five bacterial inactivation cycles in Fig. 8f. The discoloration was due to the accumulation of the colourless FeO after in the PE-FeOx samples after bacterial inactivation. The molar absorption coefficient of the $\mathrm{Fe}$ (II) band at $250-265 \mathrm{~nm}$ is $20 \mathrm{M}^{-1} \mathrm{~cm}^{-1}$ is much smaller compared to molar absorption coefficient of an $\varepsilon=1000 \mathrm{M}^{-1}$ $\mathrm{cm}^{-1}$ (ref. 16 and 17) at 366-375 $\mathrm{nm}$ as shown in Fig. $8 \mathrm{c}$ for the PE-FeOx samples.

\section{Bacterial inactivation mechanism on PE-FeOx films}

In this section we suggest a bacterial inactivation mechanism identifying the oxidative radicals intervening in bacterial inactivation on PE-FeOx. The bacterial inactivation is also investigated under aerobic and anaerobic conditions and finally the

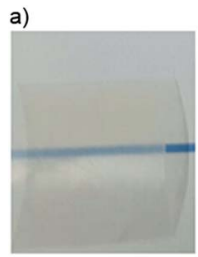

Unsputtered PE
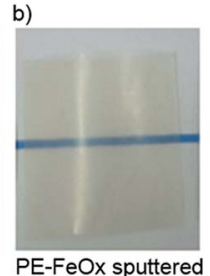
for $30 \mathrm{~s}$

e)

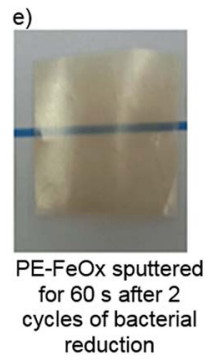

c)
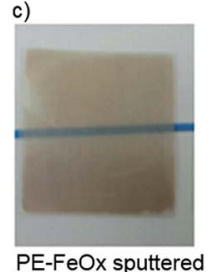

for $60 \mathrm{~s}$

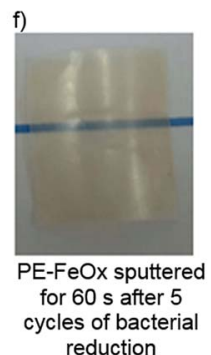

d)

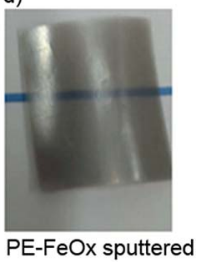

for $120 \mathrm{~s}$
Fig. 8 (a) Visual perception of samples (a) PE alone; (b-d) PE-FeOx visual perception of samples sputtered for different times; (e and f) PEFeOx samples regenerated by $1 \mathrm{M} \mathrm{NaOH}$ after two and five bacterial inactivation cycles. changes in the redox states of the PE-FeOx before and after bacterial inactivation were characterized.

(a) Nature of the radicals intervening in bacterial inactivation. Fig. 9, trace 1 shows the bacterial inactivation by PEFeOx alone (RF-plasma pretreated) under sunlight irradiation.

Scavenging the $\mathrm{OH}$-radicals with DMSO slows down bacterial inactivation but this effect seems not to be significant since the bacterial inactivation is slowed down in a very limited way. More important is the almost complete suppression of the bacterial inactivation shown in Fig. 9 by EDTA-2Na to detect the $\mathrm{vbh}^{+}$. The addition of SOD was used to detect the $\mathrm{HO}_{2} / \mathrm{O}_{2}{ }^{-}$. Both scavengers preclude almost entirely the bacterial inactivation as shown in Fig. 9.

The intervention of $\mathrm{HO}_{2}{ }^{\circ} / \mathrm{O}_{2}{ }^{-}, \mathrm{OH}^{*}$ radicals and $\mathrm{vbh}^{+}$during the $\mathrm{PE}-\mathrm{FeOx}$ mediated bacterial inactivation is suggested below:

$$
\begin{gathered}
\mathrm{PE}-\mathrm{FeOx}+h \nu \rightarrow \mathrm{h}^{+}+\mathrm{e}^{-} \\
\mathrm{e}^{-}+\mathrm{O}_{2}+\mathrm{H}^{+} \rightarrow \mathrm{HO}_{2}, E_{0}-0.05 \mathrm{NHE}^{9} \\
\mathrm{HO}_{2} \cdot \mathrm{O}_{2}^{-\cdot}, E_{0} 0.75 \mathrm{NHE}^{9} \mathrm{p} K_{\mathrm{a}}=4.8 \\
\mathrm{e}^{-}+\mathrm{O}_{2} \text { (ads) } \rightarrow \mathrm{O}_{2}^{-} \text {(ads), } E_{0}-0.16 \mathrm{NHE}^{\mathbf{1 0}} \\
\mathrm{h}^{+}+\mathrm{OHads}^{\rightarrow} \mathrm{OH}^{\cdot}, E_{0}-1.90 \mathrm{NHE}^{40} \\
\mathrm{~h}^{+}+\mathrm{H}_{2} \mathrm{Oads} \rightarrow \mathrm{OHads}^{+} \mathrm{H}^{+}
\end{gathered}
$$

(b) Aerobic and anaerobic bacterial inactivation on PEFeOx films. Fig. 10 shows the evolution in aerobic and anaerobic conditions of the bacterial inactivation by $\mathrm{PE}-\mathrm{FeOx}$. The bacterial inactivation is seen to proceed within 120 min under aerobic conditions as reported previously in Fig. 5a. No bacterial inactivation was observed in anaerobic conditions as shown in Fig. 10, trace 2 . This suggests that the highly oxidative radicals noted in eqn (1)-(6) are generated only under aerobic conditions.

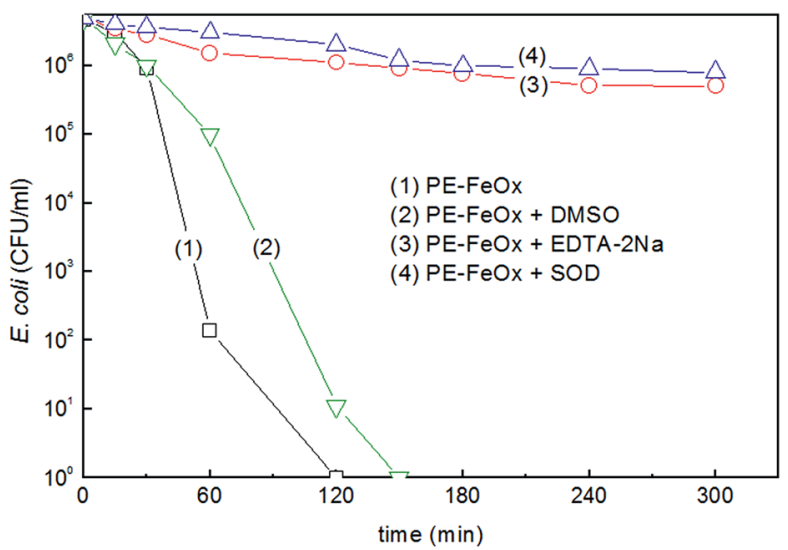

Fig. 9 Bacterial inactivation by PE-FeOx sputtered for 60 s under low intensity solar simulated light $\left(52 \mathrm{~mW} \mathrm{~cm}^{-2}\right)$ in the presence of: DMSO $\left(\mathrm{OH}^{\cdot}\right.$ scavenger) EDTA-2 $\mathrm{Na}\left(\mathrm{vbh}^{+}\right.$scavenger) and SOD $\left(\mathrm{HO}_{2} \cdot \mathrm{O}_{2}{ }^{-}\right.$ scavenger). For more details see text. 


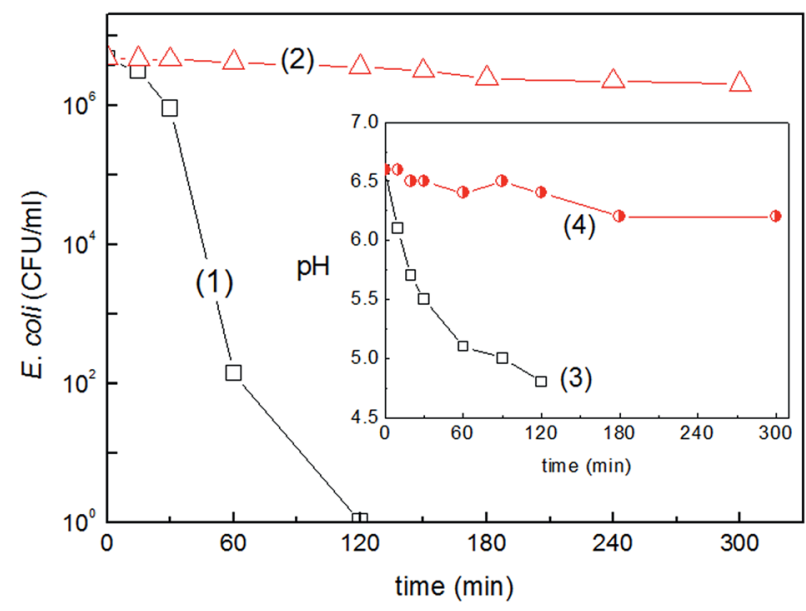

Fig. 10 E. coli reduction on $\mathrm{PE}-\mathrm{FeO}$ sputtered for $60 \mathrm{~s}$ under low intensity solar simulated light (52 $\left.\mathrm{mW} \mathrm{cm}^{-2}\right)$, traces (1) aerobic and (2) anaerobic conditions. The inset shows: trace (3) $\mathrm{pH}$ evolution during bacterial inactivation in aerobic condition and trace (4) aerobic condition.

To investigate further the nature of the oxidative radicals leading to bacterial inactivation, we measured the local $\mathrm{pH}$ changes occurring during bacterial inactivation. The inset in Fig. 10 shows the $\mathrm{pH}$ changes at the outer cell wall within 120 min, decreasing stepwise from 6.6 to 4.8 . This $\mathrm{pH}$ drop is equivalent to an increase of almost two orders (one hundred fold) in the $\left(\mathrm{H}^{+}\right)$concentration. In anaerobic conditions the $\mathrm{pH}$ decreases from a pH 6.6 to 6.4, an increase of about two times in the $\left(\mathrm{H}^{+}\right)$concentration. The decrease of $\mathrm{pH}$ under aerobic conditions can be suggested by eqn (7)-(10) below:

$$
\begin{aligned}
& \mathrm{Bact}+[\mathrm{PE}-\mathrm{FeOx}]+h \nu \rightarrow\left[\mathrm{Bact}^{*} \ldots \mathrm{FeOx}\right] \mathrm{PE} \rightarrow \\
& {\left[\mathrm{Bact}^{+\cdot}+\mathrm{FeOx}\right] \mathrm{PE}+\mathrm{cbe}^{-}} \\
& \mathrm{FeOx}+h \nu \rightarrow \mathrm{FeOx}\left(\mathrm{vbh}^{+}\right) \\
& \mathrm{vbh}^{+}+\mathrm{H}_{2} \mathrm{Oads} \rightarrow \mathrm{OH}^{\cdot} \text { ads }+\mathrm{H}^{+} \\
& \text {cbe }^{-}+\mathrm{O}_{2} \text { ads } \rightarrow \mathrm{O}_{2}^{-}
\end{aligned}
$$

(c) XPS of the redox states before and after bacterial inactivation. Fig. 11 presents the changes in the Fe-oxidation states of PE-FeOx within the $120 \mathrm{~min}$ bacterial inactivation period. It is readily seen that the initial $\mathrm{Fe}(\mathrm{III}) / \mathrm{Fe}_{2} \mathrm{O}_{3}$ at $712.2 \mathrm{eV}$ decreases from $\sim 80.0 \%$ at time zero to $\sim 53.0 \%$ after the bacterial inactivation. Concomitantly, an increase in $\mathrm{Fe}_{3} \mathrm{O}_{4}$ at $713.6 \mathrm{eV}$ and $\mathrm{Fe}(\mathrm{II})$ with peaks at $709.7 \mathrm{eV}$ was observed. ${ }^{22-24}$

This changes in the surface atomic concentration percentages is accompanied by redox processes shifting the peaks position of the FeOx photocatalyst under Suntest simulated light irradiation. After bacterial inactivation the XPS peak positions for the $\mathrm{Fe}(\mathrm{III}), \mathrm{FeO}(\mathrm{II} / \mathrm{II})$ and $\mathrm{Fe}(\mathrm{II})$ peaks were: $711.4 \mathrm{eV}$; $711.4 \mathrm{eV} ; 708.6 \mathrm{eV}$ and $713.8 \mathrm{eV}$ respectively. The three Fe-oxides in Fig. 11 offer different potentials to catalyze the bacterial reduction inherent to its own oxidation states. No accumulation of residual intermediates on the catalyst after bacterial

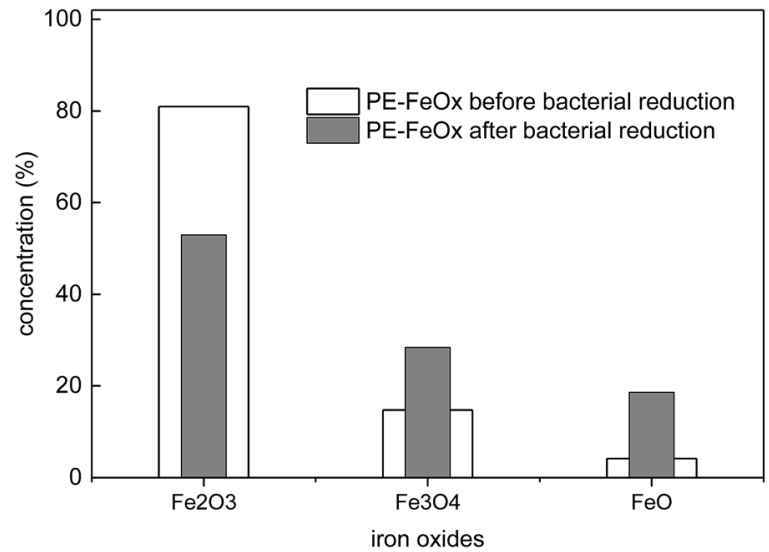

Fig. 11 XPS investigation of iron oxide oxidation states on the PEFeOx surfaces sputtered for $60 \mathrm{~s}$ before and after bacterial inactivation under solar simulated light $\left(52 \mathrm{~mW} \mathrm{~cm}^{-2}\right)$.

inactivation as shown by the decrease of the C-content on the catalyst surface in Table 3 .

(d) Mechanistic features of PE-FeOx mediated bacterial inactivation. Fig. 12 suggests a mechanism for the bacterial inactivation on $\mathrm{PE}-\mathrm{FeOx}$ reaction. The electrostatic attraction of the negatively charged $E$. coli at pH between 3 and 9 and the slightly positively charged $\mathrm{PE}-\mathrm{FeOx}$ due to the Fe dense electronic charge is the dominant effect at distances below $4 \AA$, polarizing strongly the interaction between both species within this short distance. ${ }^{33-36} \mathrm{Fe}_{2} \mathrm{O}_{3}$ presents a cb at $+0.1 \mathrm{eV}$ and a vb at $+2.2 \mathrm{eV}^{35,36}$ The $\mathrm{vbh}^{+}$holes interact with the adsorbed $-\mathrm{OH}$ surface groups but do not have a high enough potential to lead to the formation of $\mathrm{OH}^{-}$-radicals. The $\mathrm{HO}_{2}{ }^{-}$-radicals oxidize bacteria undergoing $\mathrm{HO}_{2}{ }^{\circ} / \mathrm{HO}_{2}{ }^{-}$reduction at $0.75 \mathrm{eV}$, a much lower potential compared to the potential required to drive the reaction $\mathrm{OH}^{*} / \mathrm{OH}^{-}$. The $\mathrm{HO}_{2}{ }^{\cdot}$ decomposes at $\mathrm{pH}>4.8$ as set for the bacterial inactivation runs (Fig. $4 \mathrm{a}$ and 10) driving the local $\mathrm{pH}$ to a more acidic local $\mathrm{pH}$ as shown below in eqn (11)

$$
\mathrm{HO}_{2}+\mathrm{Fe}^{3+} \rightarrow \mathrm{Fe}^{2+}+\mathrm{O}_{2}+\mathrm{H}^{+}
$$

The $\mathrm{Fe}_{2} \mathrm{O}_{3}$ is reduced in the initial stages while oxidizing bacteria.

This is shown in Fig. 8 when Fe(III) transforms to Fe(II) and further confirmed by the XPS experiments reported in Fig. 11. The $\mathrm{Fe}_{3} \mathrm{O}_{4} / \mathrm{FeO}$ produced in this first step in Fig. 11 subsequently re-oxidizes to $\mathrm{Fe}_{2} \mathrm{O}_{3}$ in aerobic media. The conduction

Table 3 Surface atomic percentages concentration determined by XPS on PE-FeOx sputtered for $60 \mathrm{~s}$ before and after bacterial reduction under solar irradiation $\left(52 \mathrm{~mW} \mathrm{~cm}^{-2}\right)$

\begin{tabular}{lcc}
\hline & Before bacterial inactivation & After bacterial inactivation \\
\hline Fe 2p & 7.87 & 7.39 \\
O 1s & 31.11 & 35.27 \\
C 1s & 61.02 & 57.34 \\
N 2p & 0.9 & 1.19
\end{tabular}




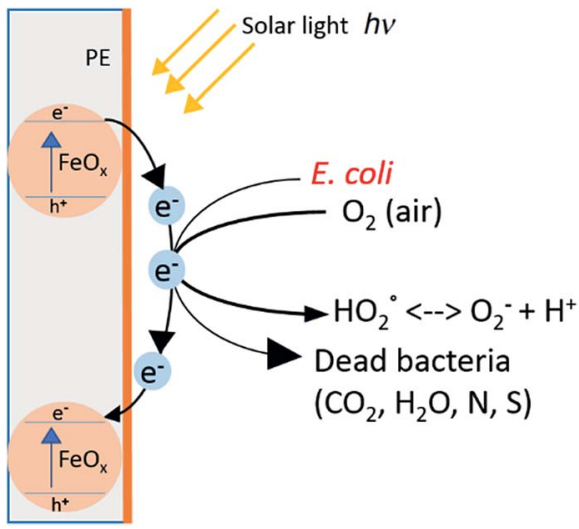

Fig. 12 Mechanism suggested for the bacterial inactivation mechanism under solar simulated light on PE-FeOx sputtered surfaces.

Table 4 Amount Fe-ions release during E. coli bacterial reduction on $\mathrm{PE}-\mathrm{FeOx}$ surfaces determined by inductive coupled plasma massspectrometry ICP-MS

\begin{tabular}{ll}
\hline & Fe (ppb) \\
\hline FeOx sputtered for $30 \mathrm{~s}$ & 0.5 \\
FeOx sputtered for $60 \mathrm{~s}$ & 0.6 \\
FeOx sputtered for $120 \mathrm{~s}$ & 0.9
\end{tabular}

band of $\mathrm{Fe}_{2} \mathrm{O}_{3}$ at $-0.1 \mathrm{~V}$ is at a more positive potential than the potential required for the one electron oxygen reduction $\mathrm{O}_{2}+\mathrm{H}^{+}$ $+\mathrm{e}^{-} \rightarrow \mathrm{HO}_{2}{ }^{-}(-0.22 \mathrm{~V}) .^{2}$ This precludes the consumption of $\mathrm{H}^{+}$ allowing the $\mathrm{H}^{+}$to drive the local $\mathrm{pH}$ towards more acidic values as shown in the insert in Fig. 10.

One of most important finding in this study relates to the PE-FeOx mediated bacterial reduction in Fig. 4a, trace 1 showing the bacterial inactivation for PE-FeOx sputtered for 60 s. The amount of Fe-released within the inactivation time is shown in Table 4.

The released FeOx was $<1$ ppb, far below the $200-400$ ppb Feconcentration reported to be toxic to mammalian cells. ${ }^{37-39}$ The $\mathrm{PE}-\mathrm{FeOx}$ mediated disinfection would proceed with practically no loss of $\mathrm{Fe}^{40,41}$

The cytotoxic effect of $\mathrm{PE}-\mathrm{FeOx}$ on bacteria could be rationalized by the formation of a Fe-C composite at the $\mathrm{PE}-\mathrm{FeOx}$ film interface. This composite at the interface would be highly toxic even at low levels of $\mathrm{Fe}^{42}$ In the petrochemical industry C-metal interfaces present an increase catalytic activity compared to metal NP's alone. ${ }^{43}$ Our findings in this study are very different to the subjects reported in many recent studies where Fe has been reported to be released from Fe-heterogeneous catalysts during degradation of pollutants/bacteria in solution leading to Fenton reactions, but in the presence of Fe in the ppm-range. ${ }^{16-18,33,34}$

\section{Conclusions}

The synthesis, material chemistry and microstructure of innovative $\mathrm{PE}-\mathrm{FeOx}$ films are reported in this study. Due to the subppb leaching of Fe of 0.5-0.6 ppb out of PE-FeOx, the FeOx catalytic action intervening in the bacterial inactivation at an extremely low level of Fe-leaching allows the disinfection of $E$. coli to proceed with no cytotoxicity on mammalian cells. The efficient bacterial inactivation proceeding with acceptable kinetics shows a potential for the future application of these films inducing repetitive bacterial disinfection. This aspect is especially important on PE where bacteria develop easily with the known adverse effects. A mechanism for the photocatalytic disinfection by PE-FeOx is suggested consistent with the experimental work carried out during the course of this study.

\section{Acknowledgements}

We thank the EPFL and Swiss National Science Foundation (SNF) Project (200021-143283/1) and the EC7th Limpid FP project (Grant No. 310177) for financial support. We also thank the COST Actions MP1101 and MP1106 for interactive discussions during the course of this study.

\section{References}

1 M. Mohapatr and S. Anand, Int. J. Eng. Sci. Tech., 2010, 2, 127-146.

2 A. Fujishima, X. Zhang and D. Tryck, Surf. Sci. Rep., 2008, 63, 515-582.

3 K. Page, G. Palgrave, P. I. Parkin, M. Wilson, P. S. L. Savin and A. V. Chadwick, J. Mater. Chem., 2007, 17, 95-101.

4 M. Pelaez, N. Nolan, S. Pillai, M. Seery, P. Falaras, A. Kontos, M. S. P. Dunlop, J. Hamilton, J.-A. Byrne, K. O'Shea, M. Enterazi and D. Dionysiou, Appl. Catal., B, 2012, 25, 331-349.

5 G. Walters and P. I. Parkin, J. Mater. Chem., 2009, 19, 574590.

6 W. Daoud, Self-cleaning Materials and Surfaces, John Wiley and Sons Ltd, 2013.

7 R. Mukh-Qasem and R. Gedanken, J. Colloid Interface Sci., 2005, 284, 489-494.

8 W. Wu, Q. He and C. Jiang, Nanoscale Res. Lett., 2008, 3, 397415.

9 L. Zhang, R. Dillert, D. Bahnemann and M. Vormoor, Energy Environ. Sci., 2012, 5, 7491-7507.

10 S. Rtimi, R. Sanjines, C. Pulgarin, A. Kulik and J. Kiwi, Surf. Coat. Technol., 2014, 254, 333-343.

11 K. Sarakinos, J. Alami and S. Konstantinidis, Surf. Coat. Technol., 2010, 204, 1661-1684.

12 K. Kever and J. Imlay, Proc. Natl. Acad. Sci. U. S. A., 1996, 93, 13635-13640.

13 R. Bauer, G. Waldner, S. Hager, T. Krutzler, S. Malato and P. Maletzky, Catal. Today, 1999, 53, 131-144.

14 J. Ndounla, D. Spuhler, S. Kenfak, J. Wethe and C. Pulgarin, Appl. Catal., B, 2013, 129, 309-317.

15 R. Ruales-Lonfat, N. Bentez, A. Sienkewicz and C. Pulgarin, Appl. Catal., B, 2014, 160, 286-297.

16 M. Dhananjeyan, E. Mielczarski, K. Thampi, P. Buffat, M. Bensimon, A. Kulik, J. Mielczarski and J. Kiwi, J. Phys. Chem. B, 2001, 105, 12046-12055. 
17 M. Dhananjeyan, J. Kiwi and R. Thampi, Chem. Commun., 2000, 1443-1444.

18 J. Fernandez, J. Bandara, A. Lopez, P. Buffat and J. Kiwi, Langmuir, 1999, 15, 185-192.

19 S. Dancer, J. Hosp. Infect., 2009, 73, 378-386.

20 I. Kramer, I. Schwebke and G. Kampf, BMC Infect. Dis., 2006, 6, 137-146.

21 R. Noimark, S. Dunhill, C. Wilson and I. P. Parkin, Chem. Soc. Rev., 2009, 38, 3435-3448.

22 Handbook of X-Ray Photoelectron Spectroscopy, ed. C. D. Wagner, M. W. Riggs, E. L. Davis and G. E. Müllenberg, Perkin-Elmer Corporation Physical Electronics Division, Minnesota, 1979.

23 A. D. Shirley, Phys. Rev. B: Solid State, 1972, 5, 4709-4716.

24 J. Nogier, M. Delamar, P. Ruiz, M. Gratzel, R. Thampi and J. Kiwi, Catal. Today, 1994, 20, 109-123.

25 O. Seddiki, C. Harnagea, l. Levesque, D. Mantovani and F. Rosei, Appl. Surf. Sci., 2014, 308, 275-284.

26 N. Turro, V. Ramamurthy and J. Scaiano, Modern Molecular Photochemistry of Organic Molecules, Univ. Science Books, 2010.

27 C. Chan, T. Ko and T. Hiroaka, Surf. Sci. Rep., 1996, 24, 1-54. 28 X. Li and Y. Oiu, Appl. Surf. Sci., 2012, 258, 7787-7793.

29 A. Kinloch, Adhesion and Adhesives, Chapman and Hall Inc, New York, USA, 1981.

$30 \mathrm{M}$. Willert-Porada, Advances in microwave and radio frequency processing in: 8th International Conference on Microwave and High-Frequency Heating, Germany, 2001, pp. 440-443.
31 S. Yumitori, J. Mater. Sci., 2000, 35, 139-146.

32 S. Rtimi, C. Pulgarin, R. Sanjines and J. Kiwi, RSC Adv., 2013, 3, 16345-16348.

33 S. Parra, I. Guasaquillo, O. Enea, J. Mielczarski, E. Mielczarski and J. Kiwi, J. Phys. Chem. B, 2003, 107, 7026-7035.

34 J. Kiwi and M. Gratzel, J. Chem. Soc., Perkin Trans. 1, 1987, 83(4), 1104-1110.

35 K. Hardee and A. Bard, J. Electrochem. Soc., 1977, 124, 215224.

36 J. Kennedy and A. Bard, J. Electrochem. Soc., 1978, 125, 723726.

37 S. Kanagesan, M. Hashim, S. Tamilsevan, A. Ismail and K. Ahsanul, Adv. Mater. Sci. Eng., 2013, 710432.

38 S. Hilger, W. Fruhauf and W. Linss, J. Magn. Magn. Mater., 2003, 261, 7-12.

39 H. Jeng and J. Swanson, J. Environ. Sci. Health, Part A: Toxic/ Hazard. Subst. Environ. Eng., 2006, 41, 2699-2711.

40 F. Mazille, T. Schottl and C. Pulgarin, Appl. Catal., B, 2009, 89, 635-644.

41 C. Ruales-Lonfat, J. Barona, A. Sienkiewicz, M. Bensimon, J. Velez Colmenares, N. Benitez and C. Pulgarin, Appl. Catal., B, 2015, 166, 497-508.

42 M. Harmer, W. Farneth and Q. Sun, J. Am. Chem. Soc., 1996, 118, 7708-7715, and references therein.

43 A. H. Foster, B. I. Ditta, S. Varghese and S. Steele, Appl. Microbiol. Biotechnol., 2011, 90, 1847-1868. 